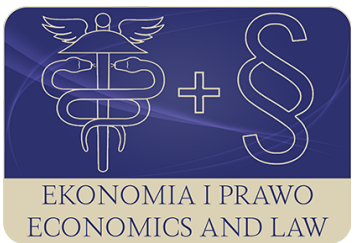

EKONOMIA I PRAWO. ECONOMICS AND LAW

Volume 16, Issue 1, March 2017

p-ISSN 1898-2255, e-ISSN 2392-1625

www.economicsandlaw.pl

EKONOMIA I PRAWO
ECONOMICS AND LAW

ORIGINAL ARTICLE

received 23.11.2016; revised 24.01.2017; accepted 31.03.2017

Citation: Wojarska, M., Marks-Bielska, R., Lizińska, W., \& Babuchowska K. (2017). Social service provision as determinant of institutional efficiency of local self-governments. Ekonomia i Prawo.

Ecomomics and Law, 16(1): 107-118. doi:10.12775/EiP.2017.008.

\title{
Social service provision as determinant of institutional efficiency of local self- governments
}

\section{MAGDALENA WOJARSKA}

corresponding author

University of Warmia and Mazury in Olsztyn, Faculty of Economics, Department of Economic and Regional Policy, ul. Oczapowskiego 4, 10-719 Olsztyn, Poland

$\square$ magdaw@uwm.edu.pl

RENATA MARKS-BIELSKA, WIESEAWA LIZIŃSKA, KAROLINA BABUCHOWSKA

University of Warmia and Mazury in Olsztyn, Faculty of Economics, Department of Economic and Regional Policy

マ renatam@uwm.edu.pl,wieslawa.lizinska@uwm.edu.pl,karolnat@poczta.onet.pl

\section{Abstract}

Motivation: The results presented in this paper constitute an element of the research performed as part of the project entitled 'Institutional Efficiency vs. Local Economic Development: Modifying Factors and Interactions'. In particular, they refer to the partial objective consisting in identification and evaluation of factors that influence the institutional efficiency at the local level.

Aim: The objective is to verify the hypothesis that communes manifesting greater activity in the financing of social services more frequently exceed the standard set of obligatory social services, undertake more advanced measures to improve their quality and availability and are able to accomplish the designated effects to a greater degree.

Results: The hypothesis was verified on the basis of secondary data (from the Local Data Bank) and primary data (collected in the course of questionnaires circulated in the sample of 1,220 communes). Using the $k$-means procedure, financial activity coefficient, participation coefficient, task implementation coefficient, effect coefficient and Pearson's coefficient, the research hypothesis was partially confirmed. 
Keywords: local government; social services; commune budget expenses JEL: H72; H41

\section{Introduction}

The most important area of operation of public sector units is provision of commonly available public services. Due to the fact that their main objective is to maximise social and not financial profit, public funds are often involved in the implementation of such services (Biernacki et al., 2013, p. 162). Budget restrictions, which apply to the public administration sector require provision of high quality services in the most efficient and profitable manner (Communication from the Commission, 2011). On the one hand, attention is attracted to the fact that governments are searching for tools and techniques, which could enable public managers to deliver quality services at a lower cost (Andrews \& Van de Walle, 2013, p. 763). Alternatively, it is postulated that focusing on 'doing more with less' may not be the best strategy for public services. Perhaps now is the time to do 'more with more', which means bringing community and business energies and resources more actively into the processes of local governance (Hambleton \& Howard, 2013, p. 48). In this context, the role of effective local government institutions grows, whose authorities can successfully use the opportunities emerging in their environment and make them contribute to the development of their communities (Wojtowicz, 2009, p. 87).

The paper is empirical and its objective is to verify a hypothesis that communes displaying greater activity in the area of financing social service provision more often go beyond the standard set of mandatory social services and undertake more advanced measures to improve their quality and availability and also accomplish the stipulated targets to a greater degree.

\section{Methods}

The results presented here constitute an element of the research performed as part of the project entitled 'Institutional Efficiency vs. Local Economic Development: Modifying Factors and Interactions'. In particular, they refer to the partial objective consisting in identification and evaluation of factors that influence the institutional efficiency at the local level. During the study, such factors were assigned to five areas: economic and social, financial, administrative and related to personnel management in commune office as well as social services; information derived from several sources was used to assess their intensity. Secondary data was collected from the Local Data Bank while primary data was collected via questionnaires circulated at the end of 2015/beginning 2016 among representatives of local authorities. 1,220 communes sent back completed and correctly answered questionnaires, which offered a return index at the level of $49.2 \%$. Assuming the confidence coefficient of 0.95 and estimated fraction size of 0.5 , the error of response from the sample amounted to 0.02 . 
To verify whether the distribution of communes according to types manifested in the sample (urban, rural, urban and rural) differs significantly from the distribution in the population (at the level of province), the chi-square test was performed ${ }^{1}$. In each case, the result was statistically insignificant $(p>0.1)$, which shows absence of significant differences between the observed distribution (in the sample) and the expected distribution (in the population).

Activity of local governments with respect to providing social services was evaluated in three aspects, i.e. financial, functional and obtained results.

The basis for the first one was analysis of expenses of commune budgets on services in the area of physical culture and sports, education, health protection, social assistance and policy, culture and protection of national heritage and public order and public safety. In each case, the object of the study was the average value of expenses between 2007 and 2015, and also changes that occured in that period, with reference to the number of residents and budget expenses in total. The applied approach offered a pool of 24 ratios (table 1), which (after examination of their information properties ${ }^{2}$ ) were used in the $k$-means clustering ${ }^{3}$. This enabled ordering the study sample and was a reference point during the analysis of primary data. The optimal variant of the classification was the division of the 1,220-element cluster of communes, which took part in the questionnaire study, into six sub-groups containing similar units with respect to the structure of analysed variables. Due to the fact that the clustering objective was to identify similarities between objects and not to arrange them hierarchically, designations assigned to clusters are to be treated as arbitrary (Wojarska et al., 2015, p. 236).

To assess the financial activity of communes in each cluster, the $W_{A F}$ coefficient was used, whose structure relied on the number of points awarded to groups I- $\mathrm{V}^{4}$ for average values of the $X_{1}-X_{24}$ ratios, in accord with the formula: highest value of ratio: 5 pts., lowest value of ratio: 1 pt. For each area of social tasks, the formula for $W_{A F}$ was as follows:

${ }^{1}$ Calculations were made in the IBM SPSS Statistics programme.

${ }^{2}$ For this purpose, variability coefficient and parametric methods were used. The analysis showed relevant variability of ratios (i.e. above 0.1) and no correlation dependency among them (assuming $r>0.9$ ).

3 The $k$-means clustering prepared by J. McQueen is a non-hierarchic object classification procedure (Stanisz, 2007, p. 128). It is commonly used to analyse large collections of data and it reduces the volume of collected information to several basic categories, which enables easy interpretation of the phenomenon and general conclusions. Applying the $k$-means clustering method enables determining typology with respect to the examined items and specification of uniform objects of analysis, where it is easier to separate systematic factors and potential cause-and-effect relations (Pietrzykowski \& Kobus, 2006, p. 302). Calculations were made in the STATISTICA programme.

${ }^{4}$ Group VI was excluded from analysis - this is discussed in a further part of the paper. 


$$
W_{A F}=\frac{\sum p_{x}}{P_{\max }},
$$

where:

$p_{x}$ - number of points awarded to the group for the position in the cluster ranking within the $x$ index $(x=1, \ldots, 24)$;

$P_{\max }-$ maximum number of points that can be collected within the area of social services $\left(P_{\max }=20\right)$.

The basis for the subsequent stage of analysis was the results of primary research, which provided answers to the following questions:

- degree of involvement of units of local government in provision of non-mandatory social services;

- measures directed at improving service quality and availability;

- efficiency of activities.

The degree of involvement of local governments in individual categories of non-obligatory social services is determined via the participation coefficient $\left(W_{U N o}\right.$ ) understood as the relation between the number of communes offering non-obligatory services and the number of communes in total declaring non-obligatory services as part of a given cluster.

Activities undertaken by local governments in individual groups were identified on the basis of the service implementation coefficient $\left(W_{Z}\right)$, calculated according to the formula:

$$
W_{Z}=\frac{\sum \alpha_{k} Z_{k}}{N \sum \alpha_{k}},
$$

where:

$\alpha_{k}$ - arbitrarily agreed weight for service $k(k=1, \ldots, 10 ; \alpha=1, \ldots, 3)$;

$z_{k}$ - number of communes, which indicated $k$ service $(k=1, \ldots, 10)$;

$N$ - number of communes in the cluster.

The efficiency of activities was evaluated on the basis of the effect coefficient $\left(W_{E}\right.$ ) calculated as follows ${ }^{5}$ :

$$
W_{E}=\frac{\sum n_{i} W_{i}}{k N},
$$

where:

$n_{i}$ - number of communes showing effects of implemented activities at the $i$-th level $(i=1, \ldots, 3)$;

$w_{i}$ - grade corresponding to the $i$ level of task implementation $(i=1, \ldots, 3)$;

$k$ - maximum grade on a scale from 0 to $k(k=3)$;

$N$ - number of communes in a cluster.

${ }^{5}$ The inspiration for preparing the coefficient was a solution proposed by Karaszewski and Sudol (1997, pp. 17-18). 
Due to the fact that the result of the assessment was limited at each stage to a numerical value from $[0,1]$ range, comparisons that enabled verification of the adopted study hypothesis were possible (Biernacki et al., 2013, p. 164). To assess the direction and the strength of the relation between the financial activity coefficient $\left(W_{A F}\right.$ ) and other measures (i.e. $W_{U N o}, W_{Z}, W_{E}$ ) Pearson's correlation was used, which may be treated as the average product of standardised value pairs (Ścibor-Rylski, 2007, p. 96).

\section{Commune Budget Expenditure On Social Services}

According to the performed analysis, performance of public services by local governments participating in the study consumed over a half of their budget expenses (62.21\% on average) between 2007 and 2015. Education had the highest level of expenditure (36.7\%); subsequently, there was assistance and social policy $(17.8 \%)$, culture and national heritage protection $(3.4 \%)$, physical culture (2.4\%), public order and citizens' safety (1.4\%) and health protection $(0.6 \%)$. The rural Chorkówka commune (Podkarpackie province) is the leader in the list, with over $77.5 \%$ of the total funds assigned to social services. At the other end of the ranking with a share amounting to $28.1 \%$ is the Kleszczów rural commune (Łódzkie province). This local government body was also exceptional on account of amounts assigned to physical culture $\left(x_{1}=6,073.39 \mathrm{PLN}\right)$, education $\left(x_{5}=3,339.57 \mathrm{PLN}\right)$, health protection $\left(x_{9}=659.13 \mathrm{PLN}\right)$ and culture and protection of national heritage $\left(x_{17}=1,297.03\right.$ PLN $)$, which greatly exceeded the expenditure of other communes. The uniqueness of the Kleszczów commune was so significant that in the course of $k$-means clustering this unit was assigned to a separate single-element cluster (marked as VI). Because of the necessity of keeping unit data confidential, this group needed to be excluded from further analysis.

Therefore, it may be assumed that the $k$-means procedure led to the division of the examined group into five different clusters. The spatial distribution of classification results is presented in picture 1 .

Cluster I was the most numerous group, encompassing almost a half of all rural communes participating in the study $(41.2 \%)$ and the largest percentage of urban and rural local governments (35.7\%). Furthermore, this group includes a majority of communes from the following provinces: Śląskie (64.4\%), Wielkopolskie (57.3\%), Opolskie (54.3\%), Małopolskie (49.0\%), Łódzkie (48.2\%), Mazowieckie (48.1\%), Podkarpackie (40.0\%), Lubelskie (34.3\%) and Kujawsko-Pomorskie (33.8\%). The next cluster (II) consisted of 120 local governments, including 2 cities, 92 rural communes and 26 urban and rural communes. Cluster III consisted of 309 units, where: 63 were urban communes, 150 rural communes and 96 urban and rural. This cluster included over a half of all urban local government units participating in the study (42.0\%) and a significant percentage of urban and rural ones (32.0\%). It also included the majority of communes from the following provinces: Dolnośląskie (58.8\%), 
Podlaskie (46.8\%) and Świętokrzyskie (41.2\%). Cluster IV featured 110 local governments, including 32 urban, 62 rural and 16 urban and rural. The last group (V) had 219 elements (16 urban communes, 148 rural, 55 urban and rural) and it included a majority of communes from the following provinces: Warmińsko-Mazurskie (75.4\%), Pomorskie (43.1\%), Zachodniopomorskie (38.0\%) and Lubuskie (35.0\%).

The activity of individual groups with respect to financing social services is described on the basis of $W_{A F}$, the values of which are presented in table 2 .

Group IV was characterised by the greatest number of fractional ratios with the highest level of intensity and in its case the total $W_{A F}$ has the highest value. It was dominant in all variants of expenses for protection of health, three ratios in the area of public order and citizens' safety, two from the area of education and one in the area of culture and physical culture and sports. The situation in group I was different, which was distinguished by average values of individual fractional ratios, which positioned it - in the majority of cases - in the last, fifth position. This referred to nine variables, including: increase in expenditure on health protection per resident, all variants of expenses on social assistance and policy and all variants of expenses on culture and protection of national heritage.

\section{Activity of Local Governments in Social Services}

The catalogue of services performed by local governments includes two basic categories of services. The first one is of obligatory services, in the case of which the commune cannot resign from financing them and the budget also must to have a financial reserve for them. The second category is of voluntary services, which are provided according to the capacity of a local government unit and there is freedom with respect to the form, manner and mode of performing them (Tarno et al., 2004, pp. 48-50).

According to the collected information, over $3 / 4$ of communes participating in the study (80.7\%) offered non-mandatory social services such as, e.g., dental services, protective immunisation, extracurricular classes and educational and integration classes for seniors. The percentage of local governments of this type was higher in urban communes $(88.0 \%)$ and lower in rural ones (77.8\%). Most local governments exceeded the standard catalogue of social services in the area of culture and sports (70.2\%), education (69.8\%), culture (66.9\%), social assistance and policy (57.5\%), health care (46.4\%), public order and safety (44.1\%).

The involvement of communes in implementation of additional services in individual clusters was determined on the basis of $W_{U N o}$ coefficient. On average, the highest share of such units was recorded in group IV ( $\left.W_{U N o}=0.796\right)$, whereas the lowest in $\mathrm{V}(0.704)$ (table 3$)$. The correlation coefficient describing the relationship between the involvement of local governments in implementation of non-obligatory services and their financial activity amounted to 0.53 , 
which in line with Sobczak's (2006, p. 161) guidelines, is to be treated as a moderate co-dependency.

The efficiency of non-obligatory services was evaluated with the use of a fourgrade scale, where: 0 - failure to accomplish the designated effects; 1 - failure; 2 - accomplishment; 3 - full accomplishment of adopted objectives. The most frequently selected answer by the respondents was 'accomplishment' and the average percentage of indications for this statement amounted to $73.2 \%$.

Effect coefficient $\left(W_{E}\right)$ was used to assess efficiency of activities in communes from clusters I-V (table 4). Its highest values, in almost all categories of social services, were achieved by local governments from group IV, whereas the lowest by units were from cluster V. According to the analysis, the correlation between the efficiency of non-obligatory activities and the financial activity of local governments was moderate and directly proportionate $(r=0.54)$.

The role, which social services play in the life of every citizen, is stimulating local government managers to ongoing improvement of their quality and availability. According to the study, a definite majority of communes (94.7\%) tried to improve this area of public services, whereas over $3 / 4$ of respondents $(78.4 \%)$ indicated that on account of numerous difficulties (financial, HR, social, etc.) the scale of such activities was limited and referred to selected areas. Only 64 local governments (out of 1,220 participating in the study) implemented relevant mechanisms in all categories of social services, whereas the highest percentage of such communes (11.8\%) was in group IV.

The most often indicated instrument for improving quality and availability of social services (applied by 78.0\% communes) was cooperation with other entities (e.g. NGOs). Upgrading the qualifications of employees involved in provision of social services ranked second $(56.0 \%)$, whereas third was extension of social infrastructure (50.2\%).

At the stage of detailed data analysis, because of various levels of difficulty of individual services, each of them was properly valued. In line with the adopted scheme, simplest functions (e.g. systematic diagnosing of residents' needs) had weight 1 , whereas the most difficult ones (e.g. implementation of social innovations) had weight 3 . Such information was used to build the service implementation coefficient $\left(W_{Z}\right)$, which was used to assess the situation in groups I-V. The coefficient values together with assessment of activity efficiency $\left(W_{Z}\right)$ are presented in table 5 .

The power of correlation of the two categories compared with the financial activity coefficient ( $W_{A F}$ ) was varied and amounted to 0.53 (for $W_{Z}$ ) and -0.02 (for $W_{E}$ ). The obtained results suggest that communes with higher expenditures on social services more often apply more complex instruments improving quality and availability of services. Simultaneously, it is shown that there is no dependency between the financial activity of local governments and efficiency of implemented solutions. 


\section{Conclusion}

The discussion in the paper was directed at verifying the hypothesis assuming that communes manifesting greater activity in the area of financial social services more frequently go beyond the standard set of obligatory social services, undertaking more advanced activities to improve their quality and availability and also accomplish the effects to a greater degree. The group of financially most active local governments was identified with the use of the $k$-means clustering method and values of the $W_{A F}$ (financial activity coefficient). Limiting the discussion to the group of units characterised by the highest amount of financial coefficients with highest levels (in the cluster scale I-V) it may be concluded that - with one exception - the hypothesis was confirmed positively. The exception was efficiency of activities intended to improve the quality and availability of social services, which, in the analysed group, reached the level placing the cluster in the second position.

The situation is not so clear when the range of discussion is extended to other groups of communes. Relying on the results of correlation analysis, it is to be ascertained that the relationship between financial activity of local governments and their involvement in implementation of non-obligatory services and activities intended to improve the quality and availability of social services was moderately intense. The situation was similar with the level of implementation of the objectives, yet only in reference to non-obligatory tasks. In the case of activities improving the level and availability of services, no correlation was determined.

\section{References}

Andrews, R., \& Van de Walle, S. (2013). New Public Management and Citizens' Perceptions of Local Service Efficiency, Responsiveness, Equity and Effectiveness. Public Management Review, 15(5). doi:10.1080/14719037.2012.725 757.

Biernacki, M., Ejsmont, W., Łyko, J., \& Maciuk A. (2013). Propozycja syntetycznego miernika oceniającego działalność instytucji użyteczności publicznej. Zarządzanie publiczne, 2(22). doi:10.4467/20843968ZP.13.014.1188.

Communication from the Commission to the European Parliament, the Council, the European Economic and Social Committee and the Committee of the Regions. A Quality Framework for Services of General Interest in Europe $(\mathrm{COM}(2011) 900)$.

Hambleton, R., \& Howard, J. (2013). Place-Based Leadership and Public Service Innovation. Local Government Studies, 39(1). doi:10.1080/03003930.20 12.693076 .

Karaszewski, W., \& Sudot, S. (1997). Empirical Research on the Process of Transformation of Polish Companies in the Period of 1990-1995. Torun: Wydawnictwo UMK. 
Local Data Bank. (2016). Retrieved 24.01.2017 from https://bdl.stat.gov.pl.

Pietrzykowski, R., \& Kobus P. (2006). Zastosowanie modyfikacji metody $k$-średnich w analizie portfelowej. Ekonomika i Organizacja Gospodarki Żywnościowej, 60.

Sobczak, M. (2006). Statystyka - aspekty praktyczne i teoretyczne. Lublin: Wydawnictwo UMCS.

Stanisz, A. (2007). Przystępny kurs statystyki z zastosowaniem STATISTICA PL na przyktadach z medycyny. Tom 3. Analizy wielowymiarowe. Kraków: StatSoft Polska.

Tarno, J.P., Sieniuć, M., Sulimierski, J., \& Wyporska J. (2004). Samorząd terytorialny $w$ Polsce. Warszawa: LexisNexis.

Wojarska, M., Marks-Bielska, R., \& Babuchowska, K. (2015). Instytucje otoczenia biznesu w województwie warmińsko-mazurskim - próba typologii z uwzględnieniem konkurencyjności i innowacyjności. Europa Regionum, 22. doi:10.18276/er.2015.22-17.

Wojtowicz, D. (2009). Determinanty sprawności instytucjonalnej samorządów terytorialnych - w stronę trwałego Rozwoju społeczno-gospodarczego. Journal of Management and Business Administration. Central Europe, 17(3).

Ścibor-Rylski, M. (2007). Miary związku pomiędzy zmiennymi- współczynnik korelacji. In S. Bedyńska, \& A. Brzezicka (Eds.), Statystyczny drogowskaz. Praktyczny poradnik analizy danych w naukach spotecznych na przyktadach z psychologii. Warszawa: SWPS Academica.

\section{Acknowledgements}

Author contributions: authors have given approval to the final version of the article. Authors contributed to this work as follows: M.W., R.M-B., W.L., K.B. developed the concept and designed the study; M.W., R.M-B., W.L., K.B. collected the data; M.W. analysed and interpreted the data; M.W. prepared draft of article; M.W., R.M-B., W.L., K.B revised the article critically for important intellectual content.

Funding: this research was undertaken as part of the project 'Institutional Efficiency vs. Local Economic Development: Modifying Factors and Interactions' and was fully funded by a grant (DEC-2013/09/B/HS4/03039). 


\section{Appendix}

Table 1 .

Fractional ratios used to assess financial activity of communes (in years 2007-2015)

\begin{tabular}{|c|c|}
\hline Area & Ratio \\
\hline \multirow{4}{*}{ Physical culture } & $x_{1}$ - expenditure per resident (average) \\
\hline & $x_{2}$ - expenditure per resident (increase) \\
\hline & $x_{3}$ - share of expenditure in total expenses (average) \\
\hline & $x_{4}$ - share of expenditure in total expenses (increase) \\
\hline \multirow{4}{*}{ Education } & $x_{5}$ - expenditure per resident (average) \\
\hline & $x_{6}-$ expenditure per resident (increase) \\
\hline & $x_{7}$ - share of expenditure in total expenses (average) \\
\hline & $x_{8}-$ share of expenditure in total expenses (increase) \\
\hline \multirow{4}{*}{ Health protection } & $x_{9}$ - expenditure per resident (average) \\
\hline & $x_{10}$ - expenditure per resident (increase) \\
\hline & $x_{I I}$ - share of expenditure in total expenses (average) \\
\hline & $x_{12}$ - share of expenditure in total expenses (increase) \\
\hline \multirow{4}{*}{ Social assistance and policy } & $x_{13}$ - expenditure per resident (average) \\
\hline & $x_{14}-$ expenditure per resident (increase) \\
\hline & $x_{15}$ - share of expenditure in total expenses (average) \\
\hline & $x_{16}-$ share of expenditure in total expenses (increase) \\
\hline \multirow{4}{*}{ Culture } & $x_{17}$ - expenditure per resident (average) \\
\hline & $x_{18}-$ expenditure per resident (increase) \\
\hline & $x_{19}$ - share of expenditure in total expenses (average) \\
\hline & $x_{20}$ - share of expenditure in total expenses (average) \\
\hline \multirow{4}{*}{ Public order and citizens' safety } & $x_{2 I}$ - expenditure per resident (average) \\
\hline & $x_{22}$ - expenditure per resident (increase) \\
\hline & $x_{23}$ - share of expenditure in total expenses (average) \\
\hline & $x_{24}$ - share of expenditure in total expenses (increase) \\
\hline
\end{tabular}

Source: own preparation.

Table 2.

Activity of commune clusters in financing social services (2007-2015)

\begin{tabular}{cccccc}
\hline \multirow{2}{*}{ Area of social services } & \multicolumn{5}{c}{ Group } \\
\cline { 2 - 6 } & \multicolumn{1}{c}{ I } & II & III & IV & V \\
\hline Health care & 0.40 & 0.50 & 0.50 & 1.00 & 0.60 \\
Social assistance and policy & 0.20 & 0.60 & 0.60 & 0.60 & 1.00 \\
Education & 0.85 & 0.40 & 0.35 & 0.95 & 0.45 \\
Culture & 0.20 & 0.60 & 0.65 & 0.70 & 0.85 \\
Sports and recreation & 0.60 & 0.45 & 0.55 & 0.65 & 0.75 \\
Public order and citizens' safety & 0.60 & 0.85 & 0.30 & 0.80 & 0.45 \\
Total & 0.48 & 0.57 & 0.49 & 0.78 & 0.68 \\
\hline
\end{tabular}

Source: own preparation based on Local Data Bank (2016). 
Table 3.

Involvement of communes in implementation of additional services ( $W_{U N o}$ values)

\begin{tabular}{cllrrr}
\hline \multirow{2}{*}{ Area of social services } & \multicolumn{5}{c}{ Group } \\
\cline { 2 - 6 } & I & II & III & IV & V \\
\hline Health care & 0.578 & 0.535 & 0.574 & 0.656 & 0.543 \\
Social assistance and care & 0.704 & 0.744 & 0.684 & 0.833 & 0.691 \\
Education & 0.882 & 0.860 & 0.848 & 0.911 & 0.833 \\
Culture & 0.838 & 0.884 & 0.824 & 0.811 & 0.796 \\
Sport and recreation & 0.874 & 0.895 & 0.875 & 0.878 & 0.840 \\
Public order and citizens' safety & 0.522 & 0.535 & 0.555 & 0.689 & 0.519 \\
\hline
\end{tabular}

Source: own survey.

Table 4.

Values of $W_{E}$ for non-obligatory activities

\begin{tabular}{cccccc}
\hline \multirow{2}{*}{ Area of social services } & \multicolumn{5}{c}{ Group } \\
\cline { 2 - 6 } & I & II & III & IV & V \\
\hline Health care & 0.368 & 0.368 & 0.368 & 0.433 & 0.377 \\
Social assistance and policy & 0.470 & 0.508 & 0.458 & 0.596 & 0.453 \\
Education & 0.620 & 0.628 & 0.611 & 0.663 & 0.566 \\
Culture & 0.591 & 0.651 & 0.589 & 0.578 & 0.556 \\
Sport and recreation & 0.621 & 0.636 & 0.628 & 0.637 & 0.599 \\
Public order and citizens' safety & 0.348 & 0.349 & 0.353 & 0.459 & 0.348 \\
\hline
\end{tabular}

Source: own survey.

Table 5.

$W_{Z}$ and $W_{E}$ for activities improving quality and availability of social services

\begin{tabular}{clrrrr}
\hline Area of social services & \multicolumn{5}{c}{ Group } \\
\cline { 2 - 6 } & I & II & III & IV & V \\
\hline Service implementation coefficient $\left(W_{Z}\right)$ & 0.362 & 0.312 & 0.359 & 0.414 & 0.347 \\
Effect coefficient $\left(W_{E}\right)$ & 0.710 & 0.679 & 0.676 & 0.693 & 0.688 \\
\hline
\end{tabular}

Source: own survey. 
Picture 1.

Spatial distribution of results of $k$-means clustering

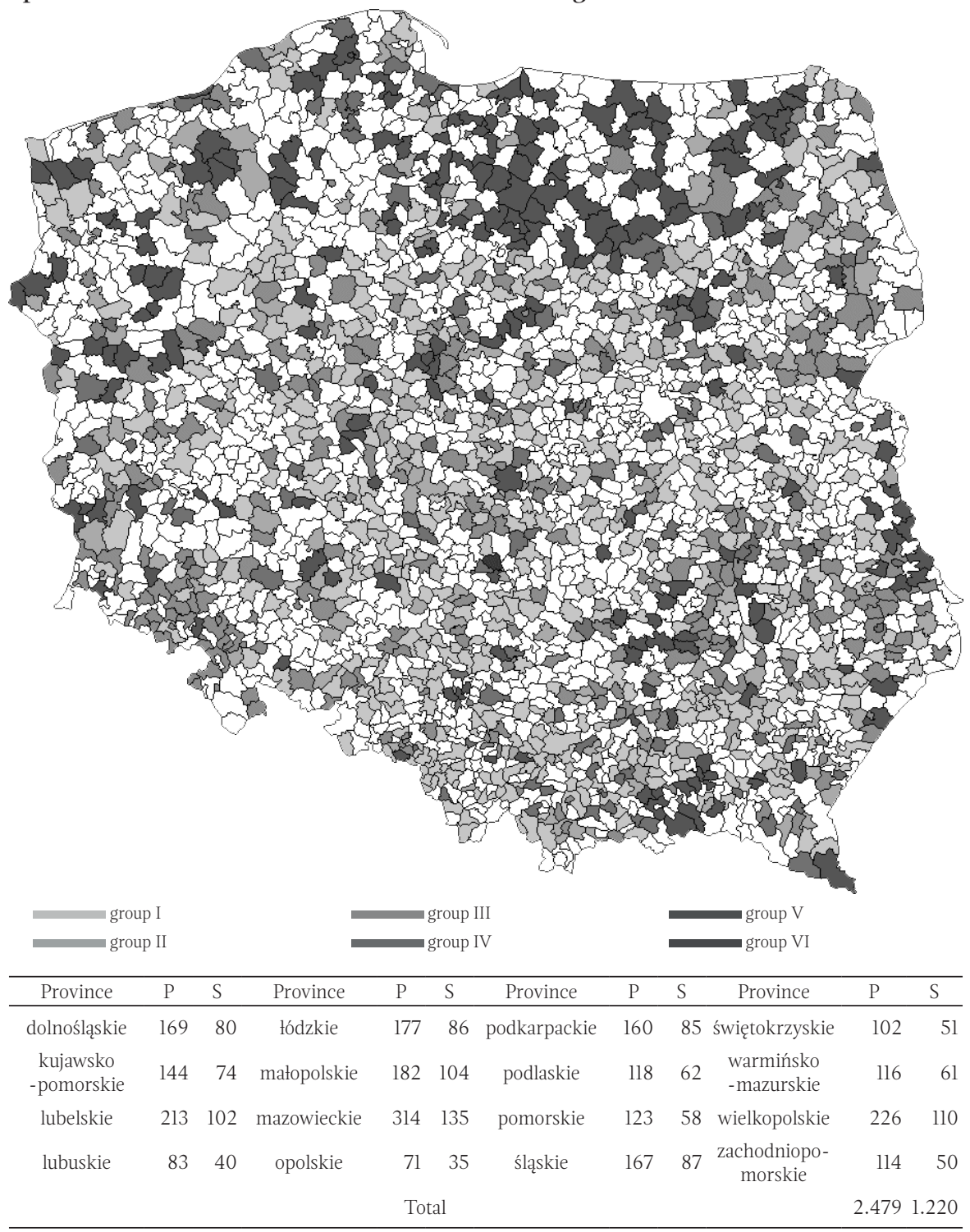

$\mathrm{P}$ - number of communes (population); $\mathrm{S}$ - number of communes (sample)

Source: own preparation based on Local Data Bank (2016) 